\title{
Comparative Study of the Cephalic Index of the Population from the Regions of the North and South of Brazil
}

\author{
Estudio Comparativo de Índice Cefálico de la Población de las Regiones Norte y Sur de Brasil
}

\author{
"H. A. Alves; " M. I. M. P. Santos; ${ }^{* *}$ F. C. L. Melo \& * R. Wellington
}

\begin{abstract}
ALVES, H. A.; SANTOS, M. I . P.; MELO, F. C. L. \& WELLINGTON, R. Comparative study of the cephalic index of the population from the regions of the North and South of Brazil. Int. J. Morphol., 29(4):1370-1374, 2011.

SUMMARY: Since the beginning of the century in various countries, investigations to determine the anthropometric characteristics of a population were carried out. The issue of miscegenation in Brazil is of great importance in this study to define a population representative data on the cranial anthropometry. The large size of Brazil, with $8.514 .876 \mathrm{~km}^{2}$ leads to an investigation between the two extreme regions of the country: North and South, because of the ethnic composition of their colonizers. This study aims to investigate, compare and rank possible differences in cephalic index of the populations from these regions of Brazil. Therefore, an anthropometric study was performed at the School of Aeronautics Expert (single training center for graduates of Brazilian Air Force), measurements were performed in 110 male students, divided by regions, and also the parents of these students who came from the same region of Brazil. The average width of the head shown in the Northern region is $15.80 \pm 0.69$ and $15.75 \pm 0.53$ in the Southern region, with significant difference $(\mathrm{P}<0.05)$. The average length of the head lodged in the Northern region is $19.54 \pm 0.61$ and 19.94 and in the South \pm 0.67 , significant difference (P $<0.05)$. With respect to the cephalic index the average in the North is $80.93 \pm 3.84$ and in the South $79.06 \pm 3.60$, significant difference (P <0.05). In the Northern region, for the classification, mesocephalic is predominant, but with a tendency to brachycephalic and hyperbrachycephalic, dolichocephalic type was rare in the South and the opposite occurs with respect to the rare type, the classification is to mesocephalic predominantly the second type is also brachycephalic, dolichocephalic but it is the third most common, often presented as the brachycephalic type.
\end{abstract}

KEY WORDS: Anthropometry; Cephalometry; Cephalic index.

\section{INTRODUCTION}

Formation of Ethnic Regions. It is rare to know a nation with such a complex and varied ethnic composition of its population, as Brazil, the population origin came basically from five different sources of migration, such as: the natives, the Portuguese, Africans, European immigration, especially in the South, the entry of immigrants from various sources, especially from Asia and the Middle East (School Brazil, 2011).

According to Rio \& Pires (1999) to ethnicity rather heterogeneous population, the uneven socioeconomic, nutritional variants have profound influence on body measurements, which hinder the establishment of anthropometric standards, so that in Brazil there is no regulation regarding anthropometric measures.
In the Brazilian State, there are 235 indigenous ethnic groups, from them about 180 are concentrated in the Northern region (Amazon), the self-declared Indians comprise $0.4 \%$ of the population (Cerqueira, 2011).

The anthropometric profile of indigenous peoples in Brazil is largely unknown, which has sparked the need for investigations, the absence of census and other surveys and the precariousness of the regular registration systems (Coimbra Jr. \& Santos, 2000).

Recent genetic studies have shown that many Brazilians are of indigenous ancestry extinct for centuries. The Brazilians who carry this genetic load in a majority are predominant in the Northern region of Brazil (Moura \&

\footnotetext{
* Instituto de Pesquisa e Desenvolvimento (UNIVAP-IP\&D), Universidade do Vale do Paraíba, São José dos Campos - São Paulo, Brazil.

*** Centro Técnico Aeroespacial (CTA), Instituto de Aeronáutica e Espaço (IAE), Divisão de Materiais (AMR). Praça Mal do Ar Eduardo Gomes, 50, Vila das Acácias, São José dos Campos/SP, Brazil.
} 
Moreira, 2001). The South Region of Brazil it is the lowest of all. It has one of the best index of economic and social development of the Country. The region has intensified the settlement only from the nineteenth century, until that time the territory was almost completely deserted, except for native peoples. Considering this factor, the government promoted a policy of settlement which attracts migrants mainly from European origin - Italian, German, consolidating the colonization of this region (Marote, 1990).

The head anthropometry. The study of the physical characteristics of man and its variations both inside and outside has been a constant concern in the course of time. The proportionality of the different body segments have interested man since antiquity (De La Rosa \& Rodriguez-Añez, 2002).

Man's skull has been studied at all times, the descriptive point of view, more recent comparative studies that have identified specific characteristics with regard to race, ethnicity, gender, age and other factors (del Sol, 2005).

The study of craniofacial relations and variations in humans has been used for different racial groups in physical anthropology. Morphology and characteristics of different races and ethnic groups are not randomly distributed but it appears in geographic clusters (Argyropoulos \& Sassouni, 1989).

Anthropometry of the head can be divided according to Grau et al. (2001) in:

I. Cephalometry: is the name given to the morphological study of all structures present in a human head, is the measurement of magnitudes of the head can be applied in the individual alive.

II. Craniofacial relations: which is limited to measuring bones and teeth directly in the dry skull.

Cephalometry is a technique that summarizes the anatomical complexities of the head of a human being living within a geometrical framework (Moyers cited by Ferreira, 2005). The cephalic index is a widely used anthropometric parameter in determining the racial variations, and very unusual use to determine sex differences, especially in individuals whose identity is unknown (Shah \& Jadhav, 2004). According to Williams et al., (1995) the cephalic index is: maximum head width / head length $x 100$ Max. He gives us an idea of how genetic traits have been passed on among parents and their offspring and siblings (Shah \& Jadhav).

Due to its validity and practicality and has a great reputation in the mandatory investigation of the craniofacial skeleton (McIntyre \& Mossey, 2003).
Williams et al. presents the cephalic index in four groups: I. Dolichocephal, II. Brachycephal, III. Mesocephal, and IV. Hyperbrachycephal.

The type of head and face depend on many factors such as ethnicity, genetic influence, traditions, nutrition, certain pathology conditions, environment and climate (Rexhepi \& Meka, 2008). For Verdun et al. (1958) the hyperdolicocephal is usually a sign of the crossing of two dolichocephalic breeds, while hiperbrachcephal indicates the crossing of two breeds brachycephalic, mesocephalic being a sign of the crossing of two breeds of cephalic index opposites.

It is believed to be needed for several multicenter some more studies to establish anthropometric data which define the reality in Brazil (Oliveira et al., 2007). For Mota et al. (2004) there is a need of studies in regions into the distinct characteristics.

\section{MATERIAL AND METHOD}

Methodology. Descriptive analysis, non-experimental crosssectional pure, where variables had no systematic observation, however manipulated. The research was investigated and classified according to differences in cephalic index established by Williams et al.

Population and Sample. The group studied in this work was composed of 54 male subjects from the Northern Region and 56 male subjects from Southern Brazil aged (17 to 28 years), all students from the School of Aeronautics Expert (the only training center for graduates of the Brazilian Air Force). The parents of these students also come from the same region of Brazil.

Data Collection. All measurements were taken with the subject sitting in the chair, in relaxed condition and head in anatomical position.

For measurements we used a millimetric caliper, by performing the following steps:

I. Head length $=$ distance between the glabella and the occipital point.

II. Head width = breadth, at right angles to median plane .

The cephalic index is given by the following formula:

III. Head Index = head width $/$ head length $\mathrm{x} 100$ Max. 
The result of the cephalic index is presented in four groups according to (Table I), according to the classification Williams et al.:

Table I. Classification head shape based on cephalic index.

\begin{tabular}{ll}
\hline Head shape & Cephalic index $($ CI $)$ \\
\hline Dolichocephalic & $70<74.9$ \\
Mesocephalic & $75<\mathrm{CI}<79.9$ \\
Brachycephalic & $80<\mathrm{CI}<84.9$ \\
Hyperbrachycephalic & $85 \mathrm{CI}<89.9$ and CI $<89.9$ \\
\hline
\end{tabular}

Analytical Procedures. Statistical analysis as performed with emphasis on the following indicators: Mean, standard deviation and to compare the results of the regions we used the Student t-test, through the BioStat 5.0.

The procedure for data collection (non-invasive procedure) was approved by the Research and Ethics at the University of Vale do Paraiba under No. H145/CEP2010, according to Resolution 196/96 of the National Health Council (Brazil).

\section{RESULTS}

The results of the mean and standard deviation of head width, head length and cephalic index in subjects from Northern and Southern Brazil are presented on Table II.

Table II. Shows the results of the mean and standard deviation of head width, head length and cephalic index in subjects from Northern and Southern Brazil.

\begin{tabular}{lcc}
\hline Regions/Variable & North & South \\
\hline Maximum head breadth & $15.80 \pm 0,69$ & $15.75 \pm 0,53$ \\
Maximum head length & $19.54 \pm 0,61$ & $19.94 \pm 0,67$ \\
Cephalic index & $80.93 \pm 3,84$ & $79.06 \pm 3,60$ \\
\hline
\end{tabular}

The average width of the head of the Northern Region is $15.80 \pm 0.69$, higher than the average Southern Region $15.75 \pm 0.53$, significant difference $(\mathrm{P}<0.05)$. The average length of the head of the Northern Region is $19.54 \pm 0.61$, a result lower than the average Southern Region 19.94 \pm 0.67 , significant difference $(\mathrm{P}<0.05)$.

The cephalic index of the Northern Region which is $80.93 \pm 3.84$, in comparison greater than the average Southern Region $79.06 \pm 3.60$, significant difference ( $P$ $<0.05)$.
The results of head shape classification based on the cephalic index in subjects from Northern and Southern Brazil are presented on Table III. In the Northern region dolichocephalic 2\%, 44\% mesocephalic, $37 \%$ and $17 \%$ brachycephalic hyperbrachycephalic are classified. In the Southern region $14 \%$ dolichocephalic, mesocephalic $46 \%$, $36 \%$ and $4 \%$ brachycephalic hyperbrachycephalic are classified.

Table III. Results from head shape Classification of the North and South of Brazil in percentage (\%) based on cephalic index.

\begin{tabular}{lcc}
\hline Head shape & North (\%) & South $(\%)$ \\
\hline Dolichocephalic & 2 & 14 \\
Mesocephalic & 44 & 46 \\
Brachycephalic & 37 & 36 \\
Hyperbrachcephalic & 17 & 4 \\
Total & 100 & 100 \\
\hline
\end{tabular}

\section{DISCUSSION}

In this study, the average cephalic index for children in the Northern Region was 80.93, an average similar to the studies of Oladipo \& Olotu (2006) determined that the cephalic index for the male group of ethnic Ijaw in 80.98 , Shah \& Jadhav students in Gujarat in India with 80.42 , del Sol in a group of individuals of the Mapuche ethnic group in Region IX in Chile with 80.40 and Golalipour et al., in men in Northern Iran with 80.40.

Students in the South, the average cephalic index was 79.06, an average similar to the studies of Basu (1963) in India with K. Vangaja ethnicity, presenting cephalic index of 79.50, García \& Lips (1986) where the Northmen the Chilean-European descent (Nordic) at 79.72, Fawehinmi et al. (2008) study in Nigeria in Port Harcout with 79.80 and Bhargava \& Kher (1961) with ethnicity Barela in India with 79.80 .

The dominant type of head in this study, in the North $2 \%$ are classified as dolychocephalic, mesocephalic $44 \%$, $37 \%$ and $17 \%$ brachycephalic hyperbrachicephalic, with the kind of lower dolichocephalic incidence with $2 \%$ and the predominant type with mesocephalic $44 \%$.

In the Southern region $14 \%$ are classified dolichocephalic, mesocephalic $46 \%, 36 \%$ and $4 \%$ hyperbrachicephalic brachycephalic, and the type of the lower incidence hyperbrachicephalic with $4 \%$ and the predominant type mesocephalic with $46 \%$. 
It can be observed that the predominance in the North and South of Brazil is the mesocephalic with $44 \%$ and $46 \%$ respectively, a result which also predominated mesocephalic was found by Shah \& Jadhav in a study in India with 302 where the male students showed that $41 \%$ of students were mesocephalic, $37 \%$ brachycephalic, $14 \%$ and $7 \%$ hyperbrachycephalic dolichocephalic. In Chile the studies of del Sol also predominated mesocephalic in a study with a group of individuals of the Mapuche ethnic group in the IX Region of Chile, where the displayed result is $2 \%$ were classified dolichocephalic, mesocephalic 66\%, 28\% brachycephalic hyperbrachycephalic and $4 \%$ in this study however, the mesocephalic is very dominant with $66 \%$ of the studied group.

The brachycephalic type is also very common in the North and South of Brazil with 37\% and 36\% respectively, similar to that found by Shah \& Jadhav, with $37 \%$ for brachycephalic, and also the second predominant type of head and studies Golalipour (2006) in Northern Iran with the ethnicity of women native Fars, presented results from $36.2 \%$ to brachycephalic, and is also the second dominant type.

Regarding the rare type in the Northern Region was dolichocephalic with $2 \%$, similar to the studies of del Sol in individuals of the Mapuche ethnic group in the IX Region of Chile with $2 \%$ dolichocephalic, Shah \& Jadhav study with
198 women in India where 3\% were classified as dolichocephalic and studies of Golalipour in Northern Iran with women from ethnic Turkman presented results dolichocephalic $0.5 \%$ to $13.3 \%$ mesocephalic, $58.1 \%$ brachycephalic and $28.1 \%$ hyperbrachycephalic native Fars and $0.1 \%$ dolichocephalic, mesocephalic $9.2 \%, 36.2 \%$ and $53.6 \%$ hyperbrachycephalic brachycephalic, but this latest study presented by Golalipour the result is quite unusual for dolichocephalic $0.5 \%$ to $0.1 \%$ in Turkman and native Fars.

The rare type in the South was 4\% hiperbraquicéfalo result similar to the Eroje et al. (2010) studies, where $66.82 \%$ are dolichocephalic, mesocephalic $21.59 \%, 10.23 \%$ and $1.36 \%$ brachycephalic hyperbrachycephalic rated very rare.

With respect to variation in head shape in various races and geographical areas, it is believed that the hereditary factor mainly affects the shape of the head, however environment has secondary effects (Golalipour).

In conclusion, this study shows in the Northern region for the classification mesocephalic predominant, but with a tendency to brachycephalic and hyperbrachycephalic, dolichocephalic type was rare in the South and the opposite occurs with respect to the rare type, the rating for mesocephalic is predominantly the second type is also brachycephalic, dolichocephalic but is the third most common, often presented as the brachycephalic type.

ALVES, H. A.; SANTOS, M. I . P.; MELO, F. C. L. \& WELLINGTON, R. Estudio comparativo de índice cefálico de la población de las regiones Norte y Sur de Brasil. Int. J. Morphol., 29(4):1370-1374, 2011.

RESUMEN: Desde el comienzo del siglo en varios países, se llevaron a cabo investigaciones para determinar las características antropométricas de la población. El tema del mestizaje en Brasil es de gran importancia en este estudio para definir una base de datos representativa de la población en la antropometría craneal. El gran tamaño de Brasil, con $8.514 .876 \mathrm{~km}^{2}$ nos lleva a realizar una investigación en individuos pertenecientes a las dos regiones extremas del país: Norte y Sur, debido a la composición étnica de sus colonizadores. Este estudio tiene como objetivo investigar, comparar y clasificar las posibles diferencias en el índice cefálico de las poblaciones de estas regiones de Brasil. Por anterior, se llevó a cabo un estudio antropométrico en la Escuela de Aeronáutica de expertos (centro de entrenamiento único para los graduados de la Fuerza Aérea de Brasil). Las mediciones se realizaron en 110 estudiantes de sexo masculino, divididos por regiones, y también en los padres de estos estudiantes que vinieron de la misma región de Brasil. El ancho medio de la cabeza en los individuos de la región Norte fue 15,80 \pm 0,69 cm y 15,75 $\pm 0.53 \mathrm{~cm}$ en la Región Sur, con diferencias significativas (P $<0,05)$. La longitud media de la cabeza en los individuos de la Región Norte fue 19,54 $\pm 0,61 \mathrm{~cm}$ y 19,94 $\pm 0,67 \mathrm{~cm}$ en los individuos del Sur, diferencia significativa $(\mathrm{P}<0,05)$. Con respecto al índice cefálico en el Norte fue 80,93 $\pm 3,84$ y emn el Sur 79,06 $\pm 3,60$, diferencia significativa $(\mathrm{P}<0,05)$. En la región Norte, la mesocefalia es predominante, pero con tendencia a la braquicefalia y hiperbraquicefalia. El tipo mesocefálico predominaba en los individuos del Sur pero con distribución más hacia la braquicefalia que hacia la dolicocefalia.

PALABRAS CLAVE: Antropometría; Cefalometría; Índice cefálico.

\section{REFERENCES}

Argyropoulos, E. \& Sassouni, V. Comparison of the dentofacial patterns for native Greek and American-Caucasian adolescents. Am. J. Orthod. Dentofacial Orthop., 95(3):238-49, 1989.
Basu, A. Anthropometry of the kayasthas of Bengal. J. Anat. Soc. India, 3:20-5, 1963. 
Bhargava, I. \& Kher, G. A. A comparative anthropometric study of Bhils and Barelas of Central India. J. Anat. Soc. India, 10:2633, 1961.

Brasil Escola. Disponível em: www.brasilescola.com.br, 2011.

Cerqueira, W. Região Norte - Geografia do Brasil - Brasil Escola: www.brasilescola.com.br, 2011.

Coimbra Jr., C. E. A. \& Santos, R. V. Saúde, minorias e desigualdade: Algumas teias de inter-relações, com ênfase nos povos indígenas. Ciênc. Saúde Coletiva, 5(1):125-32, 2000.

De La Rosa, F. J. B. \& Rodriguez-Añez, C. R. O estudo das características físicas do homem por meio da proporcionalidade. Rev. Bras. Cineantropom. Desempenho Hum., 4(1):53-66, 2002.

Del Sol, M. Indice cefálico en un grupo de individuos mapuches de la IX Región de Chile. Int. J. Morphol., 23(3):241-6, 2005.

Eroje, M. A.; Fawehinmi, H. B.; Jaja, B. N. \& Yaakor, L. Cephalic Index of Ogbia Tribe of Bayesla State. Int. J. Morphol., 28(2):389-92, 2010

Fawehinmi, H. B.; Osunwoke, A. E.; Ligha, A. E. \& Okoh, P. D. A comparative study on the cephalic indices of normal growing children and children with sickle cell anaemia in Port Harcourt. J. Exp. \& Clin. Anat., 7(1):27-9, 2008.

Ferreira, C. J. Uma nova ferramenta para o estudo da cefalometria radiográfica. Dissertação (Mestrado em Informática em Saúde), Universidade Federal de São Paulo, Escola Paulista de Medicina, São Paulo, 2005.

García, H. F. \& Lips, M. W. Contribución al estudio del índice cefálico en chilenos. An. Anat. Norm., 4(1):120-3, 1986.

Golalipour, M. J. The effect of ethnic factor on cephalic Index in 17-20 years old females of North of Iran. Int. J. Morphol., 24(3):319-22, 2006.

Golalipour, M. J.; Jahanshahi, M. \& Haidari, K. Morphological evaluation of head in Turkman males in Gorgan-North of Iran. Int. J. Morphol., 25(1):99-102, 2007.

McIntyre, G. T. \& Mossey, P. A. Size and shape measurement in contemporary cephalometrics. Eur. J. Orthod., 25(3):231-42, 2003.

Grau, V.; Alcañiz, M.; Juan, M. C.; Monserrat, C. \& Knoll, C. Automatic localization of cephalometric landmarks. J. Biomed. Inform., 34(3):146-56, 2001.

Marote, J. T. D. Estudos sociais, ciências e programas de saúde. São Paulo, Ática, 1990.

Moura, H. A. \& Moreira, M. M. A População da Região Norte: processos de ocupação e de urbanização recentes. Modelos e cenários para a Amazônia: o papel da ciência. Parcerias Estrateg., 6(12): 214-38, 2001.

Mota, M.; Melo, A.; Burak, C.; Daltro, C.; Rodrigues, B. \& Lucena, R. Antropometria craniana de recém-nascidos normais. Arq. Neuro-Psiquiatr., 62(3A):626-9, 2004.

Oladipo, G. S. \& Olotu, J. Anthropometric comparison of cephalic indices between the Ijaw and Igbo tribes. Global J. Pure App. Sci., 12(1):137-8, 2006.

Oliveira, H. A.; Paixão, A. C.; Paixão, M. O. R. \& Barros, V. C. F. Estudo antropométrico do crânio de recém-nascidos normais em Sergipe. Arq. Neuro-Psiquiatr., 65(3B):896-9, 2007.

Rexhepi, A. \& Meka, V. Cephalofacial Morphological Characteristics of Albanian Kosova Population. Int. J. Morphol., 26(4):935-40, 2008.

Rio, R. P. \& Pires, L. Ergonomia: fundamentos da prática ergonômica. $2^{\text {a }}$ ed. Belo Horizonte, Health, 1999.

Shah, G. V. \& Jadhav, H. R. The study of cephalic index in students of Gujarat. J. Anat. Soc. India, 53(1):25-6, 2004.

Verdun. J.; Taille, J.; Bourdiol, R. \& Poggi, J. Contribution a l'étude de l'anthropologie raciale de la population présente de la France. Bull. Mém. Société Anthrop. Paris, 10(9):227-44, 1958.

Williams, P. L.; Warwick, R.; Dyson, M. \& Bannister, L. H. Gray Anatomia. $37^{\mathrm{a}}$ ed. Guanabara Koogan, Rio de Janeiro, 1995.

\section{Correspondence to:}

H. A. Alves

Instituto de Pesquisa e Desenvolvimento (UNIVAP-IP\&D)

Universidade do Vale do Paraíba

Av. Shishima Hifumi, 2911

Urbanova, 12244-000

São José dos Campos

São Paulo

BRAZIL

Email: henriqueaveraldo@yahoo.com.br

Received: 19-04-2011

Accepted: 11-07-2011 